\title{
Communications
}

\section{Retinal abnormalities in diseases of the blood}

\author{
J. M. HOLT AND E. G. GORDON-SMITH \\ From the Nuffield Department of Clinical Medicine, Radcliffe Infirmary, Oxford
}

Retinal haemorrhages and exudates were recognized and described in patients with blood disease during the latter part of the Igth century, but still little is known about them. Before the advent of modern haematology, Moore (1925) described the fundus oculi of nearly 100 patients with pernicious anaemia, chlorosis, blood-loss anaemia, leukaemia, and polycythaemia. Since then there have been few systematic studies. This paper describes our examinations of the retinae in all patients with diseases of the blood who were seen in this department during the course of one year. An attempt was made to define the incidence of retinopathy in the various disorders of the blood, to see if the lesions are of any diagnostic importance, and to relate the abnormalities found to the blood counts and prognosis.

\section{Selection of patients and methods}

Patients with a haemoglobin concentration of $10 \mathrm{~g}$. per $100 \mathrm{ml}$. or less, and all those with leukaemia, reticulosis, myelosclerosis, polycythaemia, multiple myeloma, hypochromic anaemia, blood-loss anaemia, and macrocytic anaemia seen in the department in one year were examined. Where appropriate, ophthalmoscopic examinations were repeated at intervals of about one month. In addition a group of ward patients, some of whom were very ill, were examined as controls and in most instances the observer did not know at the time whether the patient had a blood disease or not. The pupils were dilated before nearly every examination. Note was made of the appearance of the optic disc, the presence of exudates and haemorrhages, and whether the haemorrhages were discrete, flame-shaped, or subhyaloid. Whenever possible the retinal abnormalities were photographed. The blood counts were recorded at each examination.

\section{Results}

The proportion of patients with retinal abnormalities in each disease group is shown in Table I. I 57 patients with blood diseases were examined, but five were not included in the analysis of results. Three of these had co-existing diabetes, one had retinitis pigmentosa, and one had retinal angiomata. The anaemia in three further patients with retinal abnormalities was caused by renal failure, and these patients were also excluded. 69 control patients were examined, two of whom had retinopathies due to diabetes mellitus. Over 350 separate examinations were made during the course of the I 2-month period. 
Table I Outline of patients with blood disease examined and incidence and type of retina abnormality observed

\begin{tabular}{|c|c|c|c|c|c|}
\hline \multirow{2}{*}{ Diagnosis } & \multirow{2}{*}{$\begin{array}{l}\text { Patients } \\
\text { examined }\end{array}$} & \multirow{2}{*}{$\begin{array}{l}\text { No. with } \\
\text { retinopathy }\end{array}$} & \multicolumn{2}{|c|}{ Type of retinopathy } & \multirow[b]{2}{*}{ Papilloedem } \\
\hline & & & Haemorrhages & Exudates & \\
\hline Acute leukaemia & 33 & I 8 & 17 & 2 & I \\
\hline Chronic myeloid leukaemia & $9(+1 D)$ & 4 & 4 & o & o \\
\hline Myelosclerosis & 6 & $\begin{array}{l}4 \\
2\end{array}$ & $\begin{array}{l}\mathbf{4} \\
\mathbf{I}\end{array}$ & I & o \\
\hline Polycythaemia vera & 4 & I & o & o & I \\
\hline Aplastic anaemia & 7 & 3 & 2 & I & 0 \\
\hline Haemolytic anaemia & 8 & 2 & 2 & I & 0 \\
\hline Leucoerythroblastic anaemia & 3 & o & o & o & o \\
\hline Multiple myeloma & $22(+2 \mathrm{D})$ & 8 & 8 & 2 & o \\
\hline Other dysproteinaemias & 2 & 1 & $\mathbf{I}$ & o & o \\
\hline Chronic lymphatic leukaemia & 6 & o & o & o & o \\
\hline Reticulosis & 4 & I & o & I & o \\
\hline Pernicious anaemia & 13 & 7 & 7 & 4 & 0 \\
\hline Iron deficiency anaemia & $\begin{aligned} 35( & +\mathrm{IRA} \\
& +\mathrm{IRP})\end{aligned}$ & 4 & 3 & 3 & I \\
\hline Total blood disease & 152 & $5^{1}$ & 45 & 15 & 3 \\
\hline Cases of renal failure & 3 & 3 & 3 & 2 & 0 \\
\hline Control patients & $67(+2 \mathrm{D})$ & 4 & 4 & I & 0 \\
\hline
\end{tabular}

$\mathrm{D}=$ diabetes mellitus

$\mathrm{RA}=$ retinal angiomata

$\mathrm{RP}=$ retinitis pigmentosa

CONTROL PATIENTS

Four control patients had retinal abnormalities that could not be attributed to diabete@ or hypertension. One patient with treated pernicious anaemia of many years' standin $\$$ developed a spontaneous macular haemorrhage. Another patient with carcinomatosi was found to have a single large soft exudate in one eye. A third, awaiting prostatectomy had some small blot haemorrhages in one eye which cleared spontaneously. The fourt patient was a 39-year-old woman with acute pyelonephritis and a renal stone. She hadi a single haemorrhage in one eye (Plate I, facing p. 148) which resolved soon after the infection had been brought under control and the stone removed.

PATIENTS WITH BLOOD DISEASES

Retinal abnormalities that could not be accounted for by diabetes or hypertension were observed in $5^{1}$ of $1^{2}$ patients with blood diseases. Sometimes the lesions were difficul to find, and had not the examination been conducted with great care under mydriasis this incidence would certainly have been lower.

Acute leukaemia Eighteen of 33 patients had a retinopathy (Table I) and abnormalities్ were found during 32 of 75 separate observations (Table II). The retinal abnormalities showed no distinguishing features, except in one patient in whom the classical picture leukaemic retinitis was observed. Here the vessels were unduly tortuous and were sheathe by white streaks and there were numerous discrete haemorrhages associated with white areas (Plate 2). In the remaining patients both flame-shaped and discrete haemorrhage were seen and two developed subhyaloid haemorrhages. The haemorrhages in a numbe of patients had white centres (Plates $3,4,5$, and 6), but these were not related to a hig total white cell count. One severely anaemic patient ( $\mathrm{Hb} 5.8 \mathrm{~g}$. per Ioo ml.) had 
Table II Details of retinal abnormalities seen during separate observations in patients with blood disease

\begin{tabular}{|c|c|c|c|c|c|c|}
\hline \multirow{3}{*}{ Diagnosis } & \multicolumn{6}{|c|}{ Retinal abnormalities } \\
\hline & \multirow{2}{*}{ Total } & \multirow{2}{*}{ Retinopathy } & \multicolumn{3}{|c|}{ Haemorrhages } & \multirow{2}{*}{ Exudates } \\
\hline & & & $\overline{\text { Flame }}$ & Discrete & Subhyaloid & \\
\hline Acute leukaemia & 75 & 32 & 14 & 25 & 2 & 2 \\
\hline $\begin{array}{l}\text { Chronic myeloid leukaemia } \\
\text { Aplastic anaemia }\end{array}$ & $\begin{array}{l}29 \\
10\end{array}$ & $\begin{array}{l}6 \\
3\end{array}$ & $\begin{array}{l}\mathbf{0} \\
\mathbf{I}\end{array}$ & $\begin{array}{l}6 \\
2\end{array}$ & $\begin{array}{l}0 \\
0\end{array}$ & $\begin{array}{l}\mathbf{0} \\
\mathbf{I}\end{array}$ \\
\hline Haemolytic anaemia* & 9 & $\begin{array}{l}3 \\
3\end{array}$ & I & $\begin{array}{l}2 \\
3\end{array}$ & o & I \\
\hline Multiple myeloma & 56 & 20 & 5 & 16 & $\mathbf{I}$ & 2 \\
\hline Pernicious anaemia & I3 & 7 & 5 & 5 & o & 4 \\
\hline Iron deficiency anaemia & 35 & 4 & I & 2 & o & 3 \\
\hline
\end{tabular}

* Including patient with haemolytic anaemia secondary to chronic lymphatic leukaemia

single soft exudate in one eye. The retina of one patient not included in this survey contained soft exudates that resembled those seen in hypertension (Plate 6a). The relationship between the presence of retinopathy and the haemoglobin concentration, platelet count, white cell count, and blast cell count in 75 separate observations is shown in Figs $I$ and 2. Retinopathy was observed when the patients were more anaemic $(\mathrm{P}<\mathrm{0} \cdot 0 \mathrm{I})$ and had a lower platelet count $(\mathrm{P}<0 \cdot 02)$ and a higher percentage of circulating blast cells $(\mathrm{P}<0 \cdot 02)$. A significant correlation between the presence of retinopathy and the white cell count could not be established.

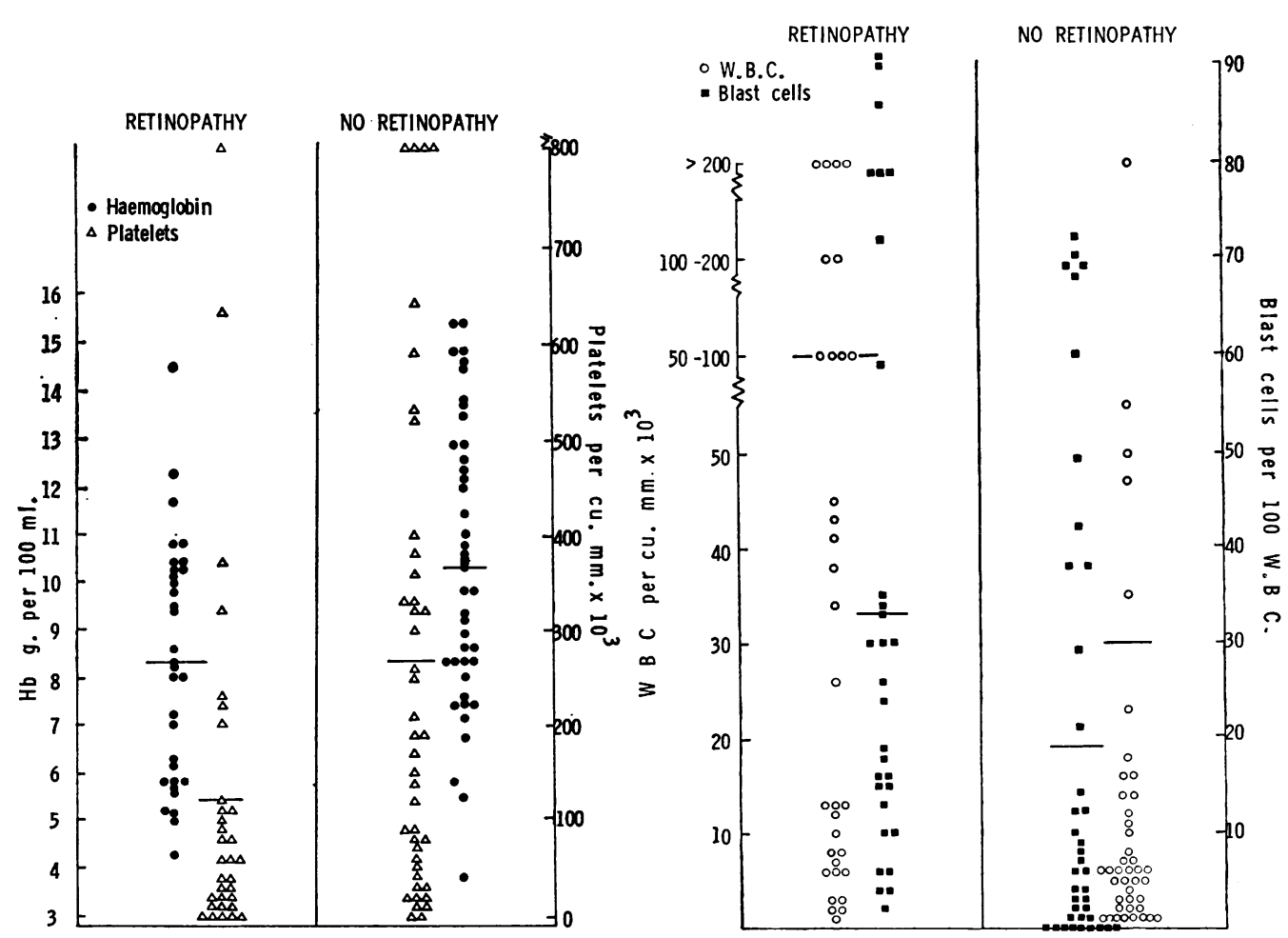

FIGS I and 2 Acute leukaemia: comparison of haemoglobin concentration, platelet count, white blood cell count, and percentage blast cells in 33 patients with and without retinopathy (75 observations) 
The retinal haemorrhages in five patients cleared during treatment but in only one instance was this accompanied by clinical and haematological improvement. The $\overline{\underline{B}}$ survival of patients with retinal abnormalities did not differ significantly from those in whom the fundus oculi was consistently normal (Fig. 3, see p. I49). Both groups included a patient who has survived over 2 years.

PLATE I Retinal photograph from a 39-year-old woman with acute pyelonephritis

PLATE 2 Acute myeloid leukaemia. The appearance conforms to the description of "leukaemic retinitis", with sheathing of blood vessels and haemorrhages associated with white areas (haemoglobin $8.3 \mathrm{~g}$. per 100 $\mathrm{ml} ., \stackrel{\omega}{\mathrm{S}}$ white blood cells 458,000 per cu. mm. (9 I per cent. blast cells), platelets 19,000 per cu. mm.)

PLATE 3 Acute myeloid leukaemia. Discrete and flame haemorrhages, some with a white centre (haemoglobin $5.2 \mathrm{~g}$. per Ioo ml., white blood cells I2,70o per cu. $\mathrm{mm}$. (35 per cent. blast cells) platelets o)

PLATE 4 Acute leukaemia. Small haemorrhage with white centre (haemoglobin $5.0 \mathrm{~g}$. per $100 \mathrm{ml}$., white $\overrightarrow{3}$ blood cells 7,00o per cu. mm. (4 per cent. blast cells), platelets o)

PLATE 5 Acute myeloid leukaemia. Flame and discrete haemorrhages. The retinopathy cleared despite. steady worsening of the leukaemia (haemoglobin $10.8 \mathrm{~g}$. per $100 \mathrm{ml}$, white blood cells 45,500 per $\mathrm{cu}$. mm. (59 per cent. blast cells), platelets 225,000 per cu. $\mathrm{mm}$.)

PLATE 6 Acute leukaemia. Haemorrhages and exudates (haemoglobin 5.8 g. per 100 ml., white blood cells $\stackrel{0}{\mathbb{Q}}$ 2,700 per cu. mm. (34 per cent. blast cells), platelets 39,000 per cu. mm.)

PLATE 6a Acute leukaemia. "Cotton wool" exudates and occasional haemorrhages (haemoglobin $6 \cdot 0 \mathrm{~g}$. pero I $00 \mathrm{ml}$., white blood cells 2,300 per cu. mm. (33 per cent. blast cells), platelets 32,00o per cu. mm.)

PLATE 7 Multiple myeloma. Haemorrhage with white centre (haemoglobin $6 \cdot 2 \mathrm{~g}$. per $100 \mathrm{ml}$., platelets. 95,00о per cu. mm., total serum proteins $7.6 \mathrm{~g}$. per 100 $\mathrm{ml}$. ("M" protein I $9 \mathrm{~g}$. per $100 \mathrm{ml}$.))

PLATE 8 Multiple myeloma. Flame and discrete haemorrhages, occasional very small exudates (haemoglobin $>$

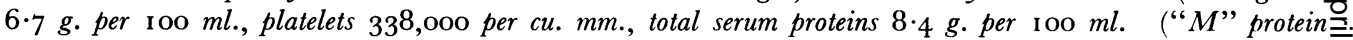
$3.7 \mathrm{~g}$. per 1 оо $\mathrm{ml}$.))

PLATE 9 Pernicious anaemia. Left eye: haemorrhages containing white areas

PLATE ga Pernicious anaemia (same patient). Right eye: "Cotton wool" exudates, few discrete haemorrhages (haemoglobin $5.8 \mathrm{~g}$. per I $00 \mathrm{ml}$.)

PLATE io Hypochromic anaemia due to occult blood loss from carcinoma of the stomach. "Cotton wool" exudutes and occasional haemorrhages (haemoglobin $6.3 \mathrm{~g}$. per I $00 \mathrm{ml}$, mean corpuscular haemoglobin concentra- $\stackrel{\mathbb{Q}}{Q}$ tion 29 per cent.) 

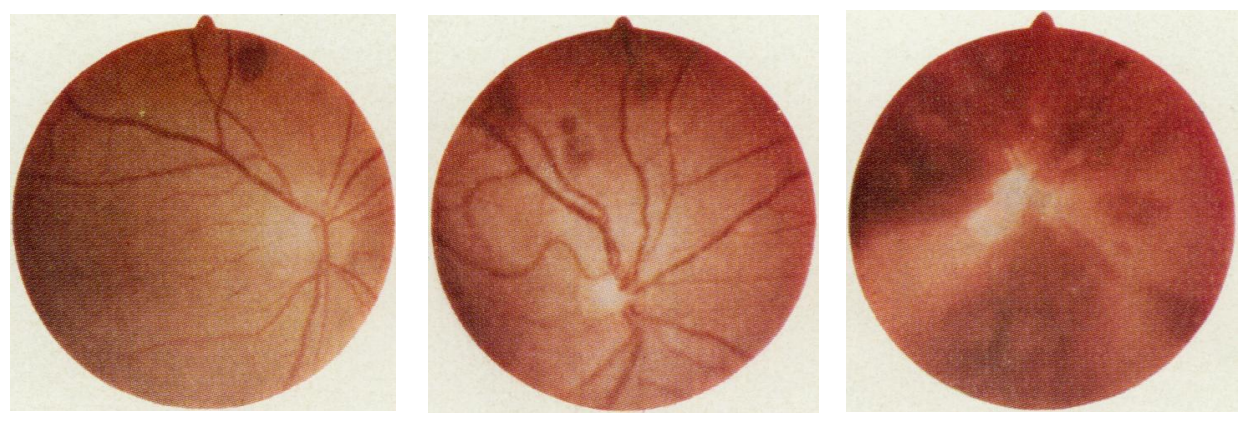

I, 2, 3
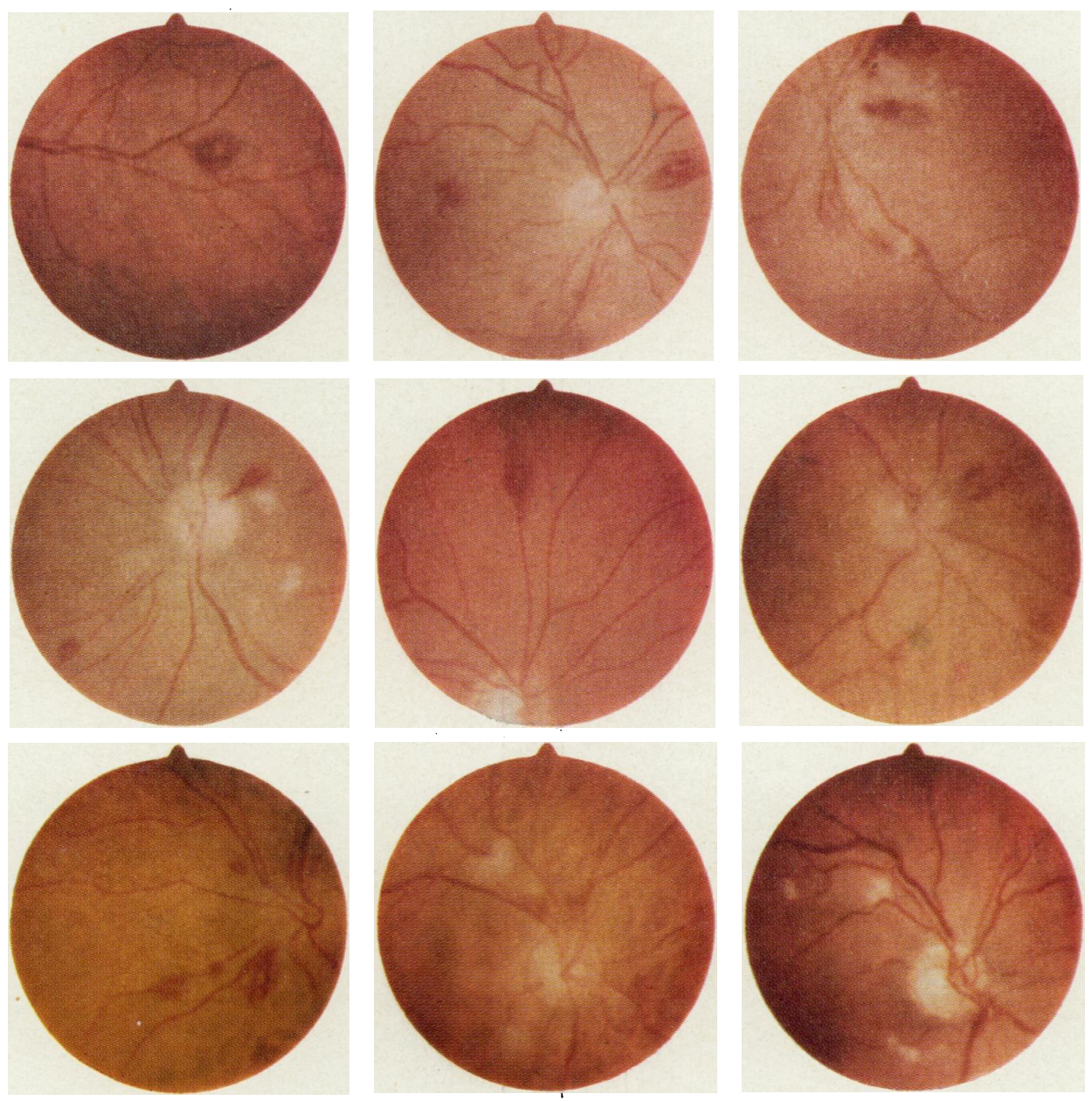

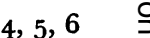

$6 a, 7,8$

융

6,7

$\stackrel{\overrightarrow{0}}{\vec{B}}$

产

흥.

훙

оั

ஓ

옥

9, 9a, 10 


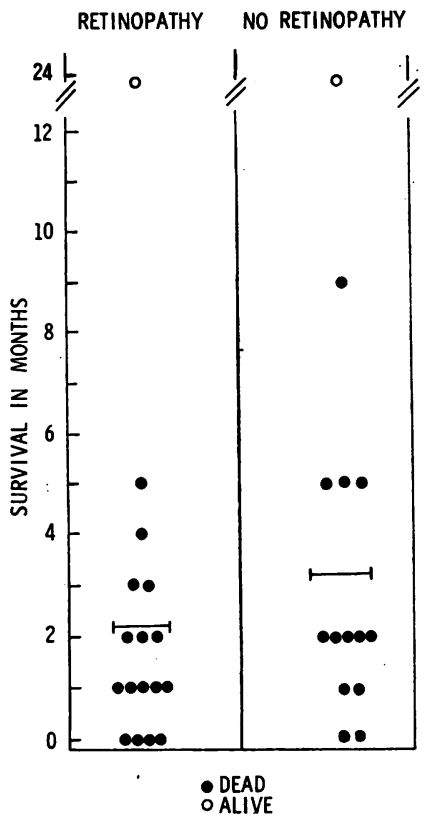

FIG. 3 Acute leukaemia: comparison of survival of 17 patients with and 14 without retinopathy

Chronic myeloid leukaemia Four of the nine patients had discrete retinal haemorrhages (Table I) and these were seen in six of 29 observations (Table II). The presence of retinopathy did not depend upon the platelet count or white blood cell count (Figs 4 and 5$)$, but occurred at a significantly lower $\mathrm{Hb}$ concentration $(\mathrm{P}<\mathrm{O} \cdot \mathrm{OI})$. The prognosis
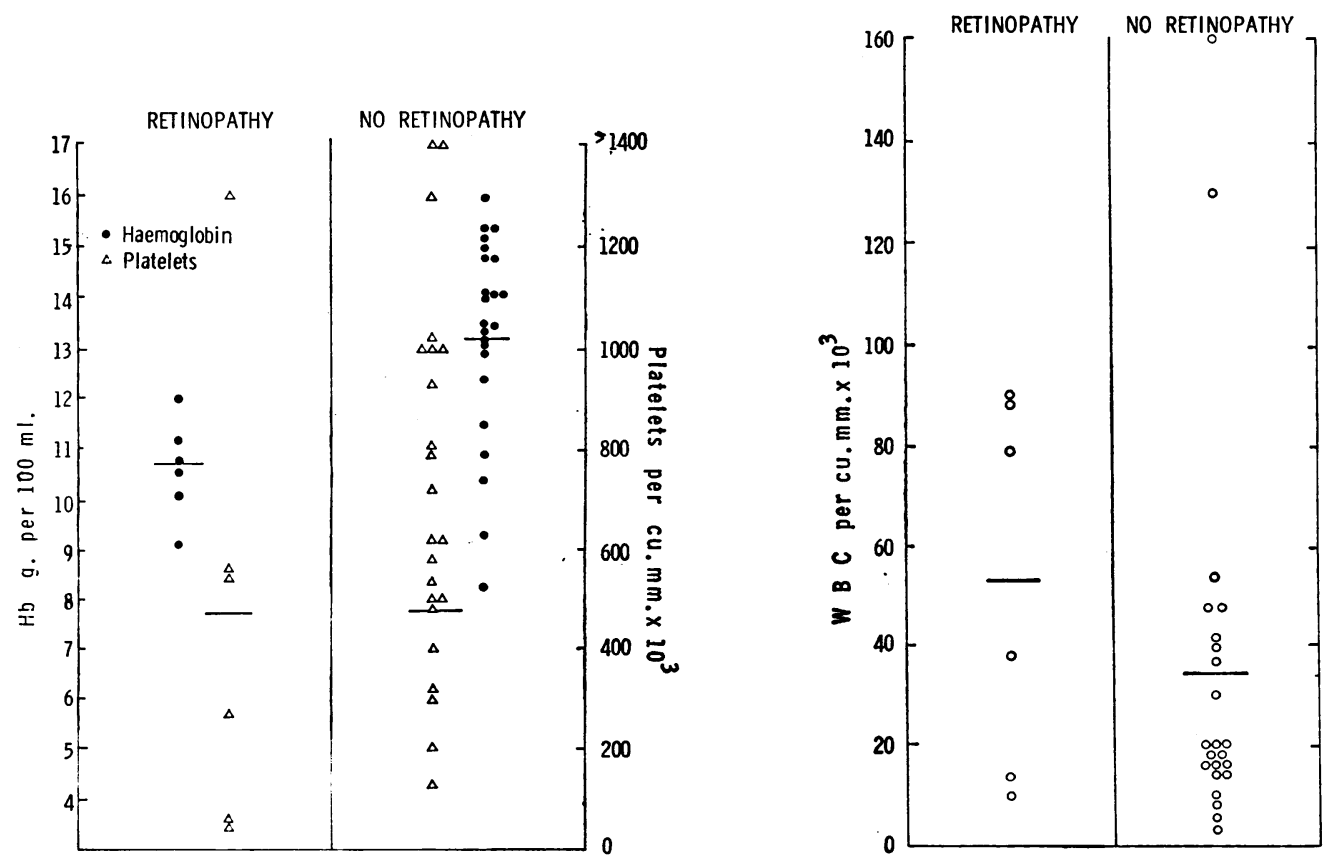

FIGS 4 and 5 Chronic myeloid leukaemia: comparison of haemoglobin concentration, platelet count, and white blood cell count in nine patients with and without retinopathy (29 observations) 
of patients with retinopathy was no worse than that of those without. The clinica course of one patient with retinal haemorrhages is shown in Fig. 6, where clearing of retinopathy coincided with a rise in $\mathrm{Hb}$ and a fall in the white cell count after treatment At no time was he severely anaemic.

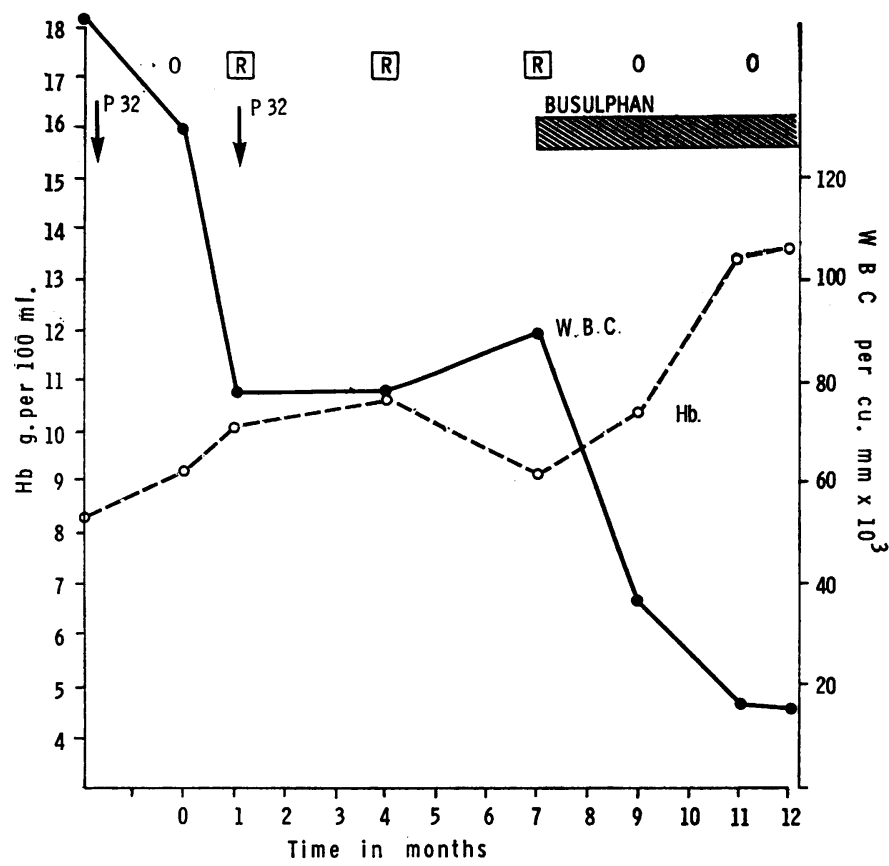

FIG. 6 Relationship of the presence of retinopathy $\mathbb{R}$ to. haemoglobin concentration and $\vec{\Delta}$ white cell count in a patient with chronic myeloid leukaemia.? $(\boldsymbol{O}=$ normal retinae $)$

Myelosclerosis Three of the six patients had retinal abnormalities (Table I). In one, haemorrhages were observed the day after a severe gastrointestinal haemorrhage from oesophageal varices. Another was markedly anaemic ( $\mathrm{Hb} 7.7 \mathrm{~g}$.) and had a single soft exudate in one eye. In the third, a number of small discrete haemorrhages developedo in one eye when the disease had reached an advanced stage. The $\mathrm{Hb}$ concentration was 3 12.0 g. per $100 \mathrm{ml}$. and the white cell count 37,000 per cu. $\mathrm{mm}$. (8 per cent. blast cells).

Polycythaemia vera One of the four patients had mild papilloedema. The Hb was $2 \mathrm{I} \cdot 5 \mathrm{~g} \cdot \circ$ per $100 \mathrm{ml}$.

Aplastic anaemia Two of the seven patients had retinal haemorrhages and one had․ exudates. The haemorrhages in one of these patients cleared completely during treatmentor with prednisolone and blood transfusion, although he remained markedly thrombocyto- 0 penic (Fig. 7, opposite).

Leucoerythroblastic anaemia The fundi in the three patients were normal. In two the anaemia was caused by disseminated carcinoma, and in one it was due to tuberculosis.

Haemolytic anaemia Two of the eight patients had retinal abnormalities. In one of these the haemolytic anaemia was secondary to chronic lymphatic leukaemia but in the othero the cause remains obscure. Of the six patients without retinopathy, one had paroxysmal nocturnal haemoglobinuria, one cold haemoglobinuria, and one thrombotic thrombocyto- $\stackrel{\mathbb{Q}}{\varrho}$ penic purpura. One of the patients with retinopathy had haemorrhages only and the 


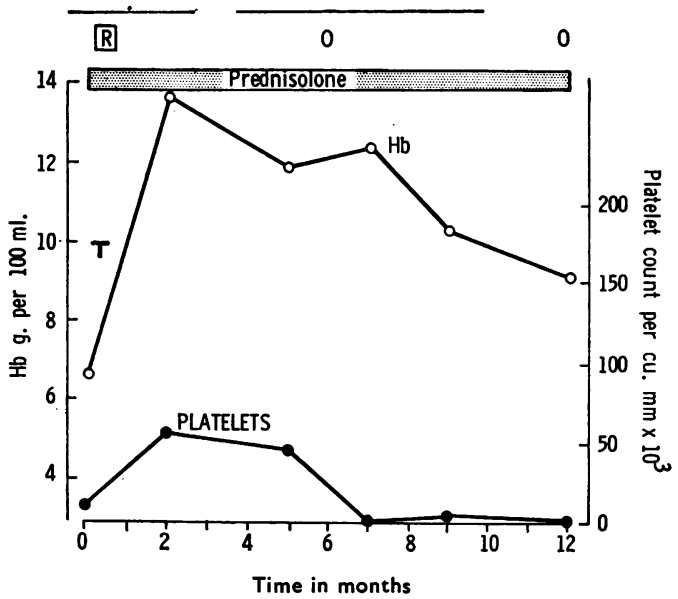

FIG. 7 Relationship of the presence of retinopathy $\mathbb{R}$ to haemoglobin concentration and platelet count in a patient with aplastic anaemia. $\quad(O=$ normal retinae, $\mathcal{T}=$ blood transfusion)

other had haemorrhages and exudates. Both these patients were severely anaemic; in one the $\mathrm{Hb}$ was 5.5 and in the other $6.7 \mathrm{~g}$. per $100 \mathrm{ml}$.

Multiple myeloma and dysproteinaemia Retinal abnormalities were observed in eight of the 22 patients with myeloma and in one patient with essential cryoglobulinaemia (Table I). Haemorrhages were seen during twenty of $5^{6}$ observations in patients with multiple myeloma, and on two occasions soft exudates were present (Table II). The retinal lesions seen had no characteristic features. The haemorrhages were most often discrete, but flame-shaped haemorrhages were not uncommon and they sometimes contained a white centre (Plates 7 and 8). Not infrequently the retinal appearances were similar to those seen in diabetes mellitus. The two patients with diabetes as well as myeloma who were not included in the analysis of the results both had retinal haemorrhages, and as the diabetes in both was mild, it is possible that the myeloma was the underlying cause.

The relationship between haemoglobin, platelet count, and the presence of retinopathy is illustrated in Fig. 8. Retinopathy was observed in patients when the haemoglobin

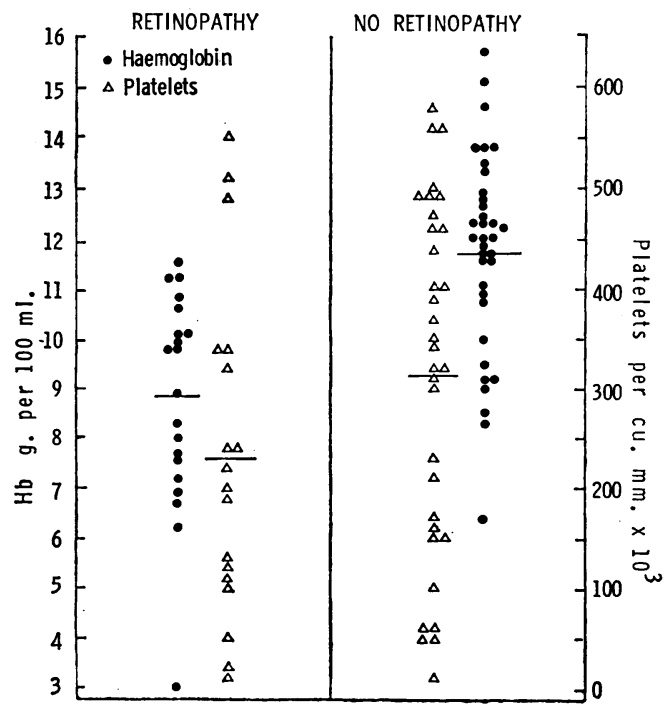

FIG. 8 Multiple myeloma: comparison of haemoglobin concentration and platelet count in 22 patients with and without retinopathy ( 56 observations) 
concentration was significantly low $(\mathbf{P}<\mathrm{O} \cdot \mathrm{OI})$, but although the platelet count tended to be lower in patients with retinopathy this was not significant. The total serum protein $\underline{\underline{3}}$ levels and the "M" protein levels in patients with retinopathy did not differ significantly from that in those in whom the fundus oculi was normal throughout (Fig. 9).

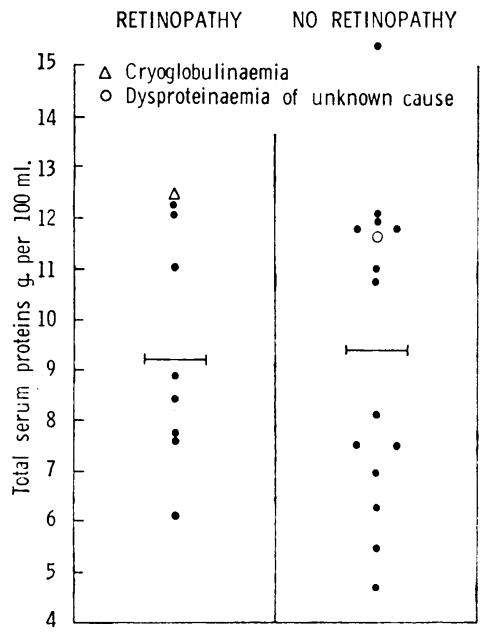

FIG. 9 Multiple myeloma and dysproteinaemia: comparison of total serum protein concentrations in nine patients with and fifteen without retinopathy

The presence of retinopathy did not significantly worsen the prognosis. Two of the eight patients with retinopathy, and four of the thirteen without, lived over 2 years after retinal abnormalities had been observed. The patient with essential cryoglobulinaemia $\frac{\mathscr{Q}}{\mathbb{8}}$ lived for more than $2 \frac{1}{2}$ years. The retinal abnormalities in four of the nine patients with myeloma, and in the patient with essential cryoglobulinaemia, cleared during treatment. The clinical course of one of these patients is illustrated in Fig. Io. This patient was one of two who developed retinal haemorrhages while the marrow was suppressed by chemotherapy. Some of the haemorrhages were subhyaloid and the vision was impaired in one eye because the macula was involved. Although the retinopathy cleared completely, vision in the affected eye did not entirely recover.

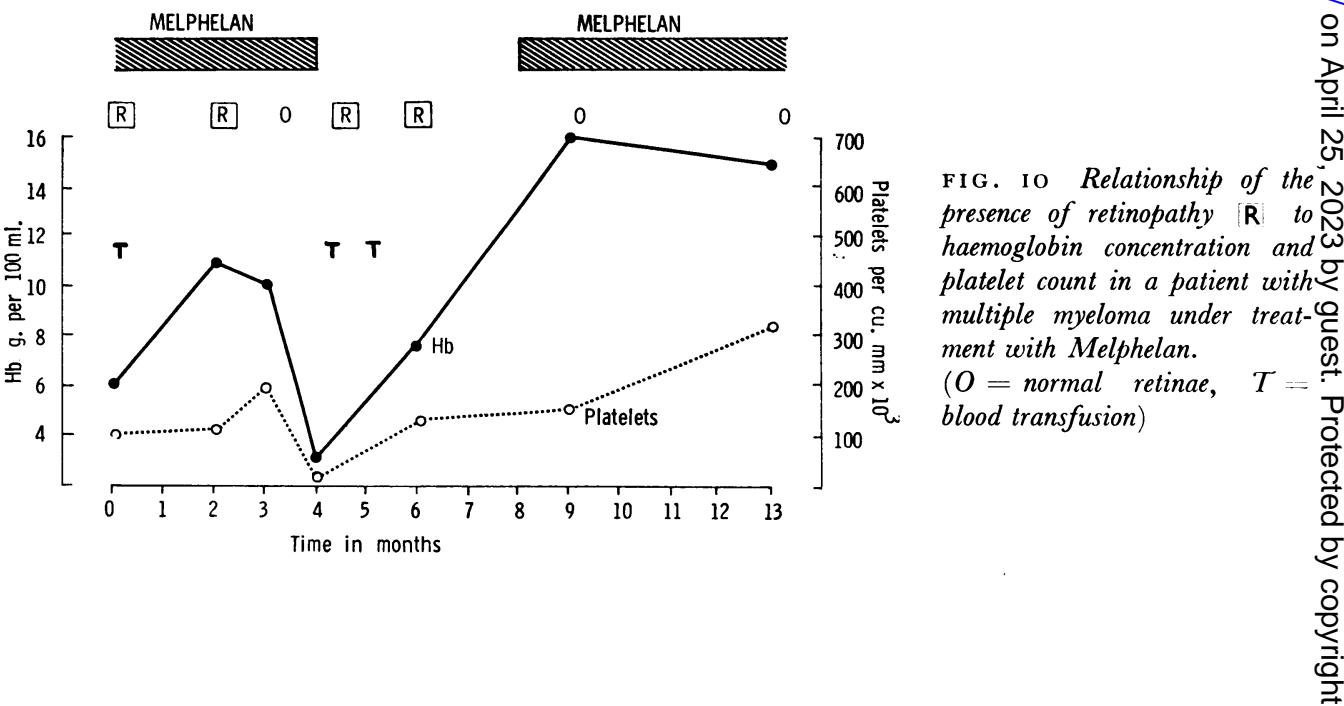


Chronic lymphatic leukaemia The retinae in the six patients with uncomplicated chronic lymphatic leukaemia were normal.

Reticulosis One patient with terminal Hodgkin's disease developed an exudate in one eye just before death. The $\mathrm{Hb}$ was I I $7 \mathrm{~g}$. per I $100 \mathrm{ml}$.

Megaloblastic anaemia Seven of thirteen patients had retinal abnormalities. The two least anaemic patients of the thirteen had folate deficiency, and the remainder had classical pernicious anaemia. Severely anaemic patients were more likely to develop retinopathy (P<0.05; Fig. I I). The platelet counts in patients with retinopathy were relatively but not significantly low, and only one patient was thrombocytopenic (platelet count* 79,000 per cu. mm.). Haemorrhages and soft exudates were seen (Table II); the haemorrhages were both flame-shaped and discrete and some had white centres (Plates 9 and $9 a$ ). The retinal abnormalities invariably cleared on treatment and the fundi in two patients were normal 5 weeks after the administration of vitamin $B_{12}$.

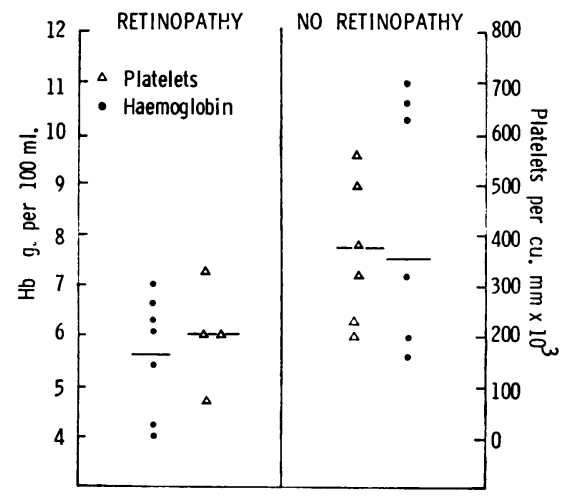

FIG. I I Megaloblastic anaemia: comparison of haemoglobin concentration and platelet count in seven patients with and six without retinopathy

Iron deficiency and blood loss anaemia Four of the 35 patients had retinopathy and all these were severely anaemic (Fig. I2). Another patient with myelosclerosis, mentioned above, developed a retinal haemorrhage the day after a severe gastrointestinal haemorrhage. Haemorrhages and soft exudates were observed, but exudates were confined to those patients who had hypochromic anaemia due to chronic blood loss (Plate ro). The margin of the optic disc in one patient, who was deliberately inducing blood loss in herself, was blurred and resembled papilloedema. The retinal abnormalities observed in all these patients cleared during treatment.

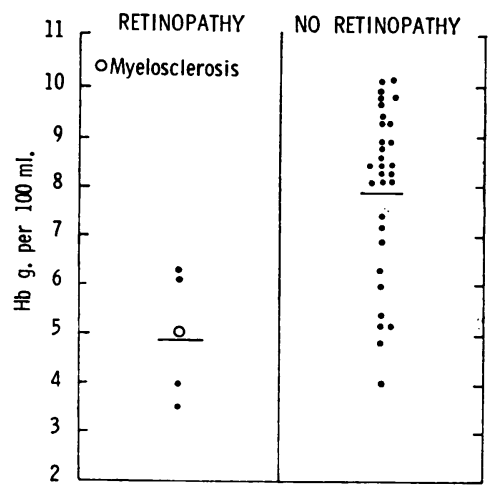

FIG. 12 Iron deficiency and blood loss anaemia: comparison of haemoglobin concentration in four patients with and $3 \mathrm{I}$ without retinopathy. (One patient also had myelosclerosis)

\footnotetext{
* Platelet counts by indirect method-normal range 200,000 to 600,000 per cu. mm.
} 


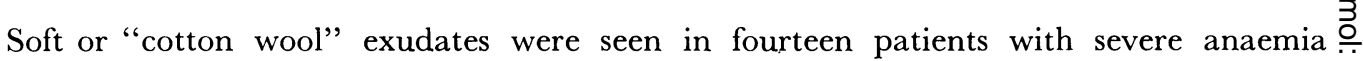
(Fig. I3). The $\mathrm{Hb}$ level was less than $6.6 \mathrm{~g}$. per $100 \mathrm{ml}$. in all but one, and the mean $\mathrm{Hb} \underset{\mathrm{F}}{\vec{\rho}}$ concentration $5.6 \mathrm{~g}$. per $\mathrm{I}$ oo $\mathrm{ml}$. They were also seen in two non-anaemic patients, one with Hodgkin's disease, and one with disseminated carcinoma (Fig. I3).

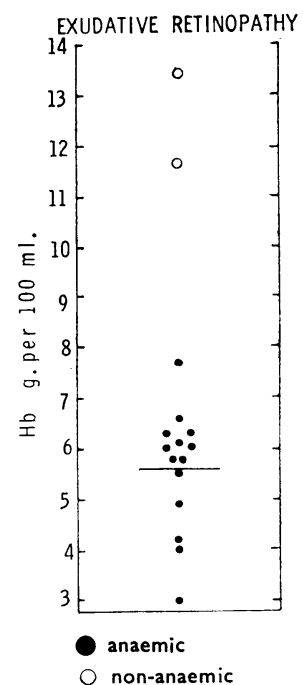

FIG. I3 "Cotton wool" exudates: haemoglobin concentration in fourteen patients with severe anaemia due to a variety of causes

\section{Discussion}

Liebreich (1863), cited by Gowers (1904), was the first to describe retinal haemorrhages $\underset{\overrightarrow{0}}{\overrightarrow{7}}$ in acute leukaemia. The impression that the ophthalmoscopic findings were charac- 3 teristic was established, and the term "leukaemic retinitis" introduced. Some years later Mackenzie ( 1878 , I 88I) described retinal haemorrhages in two patients with severe pernicious anaemia, although the clinical details suggested instead that one of these may have had acute leukaemia. Retinal haemorrhages were described in a young woman with iron deficiency by Eales ( 1884 ) and they cleared during treatment with iron. Williams ( 1884 ) and Beaumont (I89o) had similar cases with retinal exudates that they thought were identical to those seen in albuminuric retinitis. Many descriptive accounts of the 0 retinal abnormalities seen in the various diseases of the blood have since appeared; these were reviewed by Moore (1925) and more recently by Massa, de Vloo, and Jamotton 을 ( 1966 ) and Duke-Elder (1967).

Retinal haemorrhages occur commonly in leukaemia. Marshall (1959) found them in $N$ twenty of 42 patients with acute leukaemia and in twelve of $2 \mathrm{I}$ with chronic myeloid $\underset{\mathrm{N}}{\mathrm{N}}$ leukaemia. About half our patients had retinal haemorrhages at some stage of their illness. The retinal abnormalities seen varied greatly (Plates 2, 3, 4, 5, and 6) and only 6 once could the descriptive term "leukaemic retinitis", as used by Adams Frost ( 1896 ), be $\mathbb{\Phi}$ applied (Plate 2). Both Moore (1925), who found this in four of his 25 patients, and: Gowers (1904) pointed out that this so-called classical picture of leukaemic retinitis is in fact rare, yet it is still emphasized in recent books on the fundus oculi (Larsen, I964; $\stackrel{\mathbb{D}}{\Omega}$ Nover, I 966 ). It is clear that, on the whole, the retinopathies of the various disorders of $\mathbb{\mathbb { Q }}$ the blood have no diagnostic features and identical abnormalities may be seen in leukaemia, 
haemolytic anaemia, aplastic anaemia, pernicious anaemia, and myeloma. The retinopathy may be mistaken for albuminuric retinitis (Plate $6 a$ ). It is also apparent that haemorrhages with white centres are not confined to leukaemia.

The white areas seen in association with retinal haemorrhages in patients with leukaemia arise in two different ways. There is no doubt that some of these represent leukaemic infiltrates (Goldstein and Wexler, 1935; Allen and Straatsma, I96r), but they may also arise because of vascular impairment of the retina when they are composed of swollen degenerating nerve fibres (Adams Frost, I896; Allen and Straatsma, I96I). These vascular lesions are histologically similar to those that occur in the anaemia of blood loss (Ashton, Pears, and Pickering, 196r).

On the whole retinal haemorrhages occurred in leukaemic patients who were significantly more anaemic and more thrombocytopenic, and had a high percentage of circulating blast cells. This has been the impression of others (Marshall, I959), but like Gibson (1938) we found no significant relationship between the presence of retinopathy and the total peripheral white cell count. From these findings, one might reason that retinal haemorrhages occur in patients with more severe leukaemia, but like Moore (1925) and Marshall (1959) we found that the presence of retinal haemorrhages did not necessarily imply a grave prognosis. One of our patients with acute leukaemia lived for 3 years after retinal haemorrhages were first noted. Another patient with chronic myeloid leukaemia had a severe haemorrhagic retinopathy at the time of diagnosis, but has had no retinal haemorrhage in the subsequent 5 years whilst his disease has been controlled with busulphan. It has also been suggested (Marshall, 1959) that treatment may bring about the clearing of retinopathy, but as Moore (1925) recognized before the introduction of chemotherapy and effective blood transfusion services, retinal haemorrhages in leukaemia may clear spontaneously. We noticed clearing of retinal haemorrhages in two patients with acute myeloid leukaemia during a time when their haematological and clinical pictures worsened distinctly. One patient had retinal haemorrhages when first seen, and her blood count showed $\mathrm{Hb} 6 \cdot 2 \mathrm{~g}$. per I $00 \mathrm{ml}$., white blood cells 12,500 per cu. mm. (6 per cent. blast cells), platelets 3 I 3,000 per cu. mm. During the next 3 months her condition deteriorated steadily and she required periodic blood transfusion. Just before death her retinae were normal. The blood count then showed $\mathrm{Hb} \mathrm{9.2}$ g. per $100 \mathrm{ml}$., white blood cells I I 5,000 per cu. mm. (2 I per cent. blast cells), platelets 637,000 per cu. mm. A second patient had florid retinopathy when first seen (Plate 5) when the blood count showed $\mathrm{Hb}$ I $0.8 \mathrm{~g}$. per $100 \mathrm{ml}$., white blood cells 45,500 per cu. $\mathrm{mm}$. (59 per cent. blast cells), platelets 225,000 per cu. $\mathrm{mm}$. After treatment with corticosteroids for 3 weeks no retinal haemorrhages could be seen, but the blood count had worsened: $\mathrm{Hb} 5^{\cdot 2} \mathrm{~g}$. per roo ml., white blood cells 55,000 per cu. mm. (33 per cent. blast cells), platelets 79,000 per cu. $\mathrm{mm}$. Remission was not achieved despite further treatment, but the ocular fundi remained normal until she died one month later.

The retinal abnormalities seen in aplastic anaemia and haemolytic anaemia were in no way characteristic, but occurred only when anaemia was severe. It could be argued that thrombocytopenia was the major factor in the pathogenesis of retinal haemorrhages. in aplastic anaemia. The course of one of our patients (Fig. 7) shows how the haemorrhages cleared despite persistent severe thrombocytopenia during a period when the Hb level was controlled by blood transfusion and the patient was given corticosteroids. We have never seen retinal haemorrhages in adults with idiopathic thrombocytopenic. purpura in the absence of anaemia, although we have not searched for them systematically. Massa and others (I966) mentioned an infant with idiopathic thrombocytopenic purpura 
who had retinal haemorrhages and only mild anaemia (Hb 78 per cent.). Hawthorne (1922) thought that retinal haemorrhages were very rare in thrombocytopenic purpura A patient with idiopathic thrombocytopenic purpura described by Cosnett and MacLeod. (I959) had retinal haemorrhages but she was markedly anaemic, the $\mathrm{Hb}$ concentratiors being $7 \cdot 3 \mathrm{~g}$. per I $00 \mathrm{ml}$.

We saw only three patients with leucoerythroblastic anaemia, two due to disseminate carcinoma and one to tuberculosis. None had retinal abnormalities. One "control'苂 patient, who had disseminated carcinoma but was not anaemic, had a single large soft exudate in one eye, and we have since seen a further patient with a leucoerythroblastic blood film secondary to disseminated carcinoma of the stomach, who developed smal exudates associated with haemorrhages just before death. This patient had a normat్ haemoglobin concentration and platelet count. A patient with retinal haemorrhage described by Gavey ( 1963 ) had a leucoerythroblastic blood film due to disseminatec breast carcinoma, but was both severely anaemic and thrombocytopenic when the observation was made.

Retinal haemorrhages are now considered typical in Waldenström's macroglobulinaemi ڤ્ઞ (Ferriman and Anderson, I956; Martin, I960; Coyle, Frank, Leonard, and Weiner? I96I; Carr and Henkind, I963; Massa and others, I966), and are known to occur in essential cryoglobulinaemia (Carr and Henkind, ig63). There are very few reports on retinopathy in multiple myeloma (Clarke, E., 1955; Clarke, S. W., 1966) and we were surprised to find retinal abnormalities in so many of our patients. The lesions seen werह in no way helpful in diagnosis. In two patients numerous small blot haemorrhages identical to those that occur in early diabetic retinopathy were seen, and it is of interes that Jones and Ashton ( 1963 ) have demonstrated the presence of microaneurysms in the retinae of two patients with myelomas similar to those known to occur in Waldenström' macroglobulinaemia. The increased blood viscosity that occurs in Waldenström' macroglobulinaemia is believed to cause endothelial damage to small blood vessels which results in retinal haemorrhage (Carr and Henkind, 1963). We found no correlation between the presence of retinopathy and total serum protein or " $\mathrm{M}$ " protein levels? The presence of retinopathy seemed to depend more on the degree of anaemia present On reviewing some of the reported cases of Waldenström's macroglobulinaemia witlo․ retinopathy it became clear that these patients too were often severely anaemic. It is remarkable that retinal haemorrhages were never seen in one of our patients with myelomă who twice needed plasmapheresis because of severe nose bleeds. Although blood hyper응 viscosity must play a part in the pathogenesis of retinopathy in multiple myeloma, anaemiao may be of equal importance. Retinopathy in our patients with myeloma or dysprotein aemia did not signify an unusually poor prognosis and tended to clear as the diseas. process was brought under control. In two patients, fresh retinal haemorrhages occurred as the result of marrow suppression due to melphelan, and in one of these the haemorrhages were subhyaloid. Both patients went on to live for over 3 years.

Before the introduction of liver extract, pernicious anaemia was fatal and retinat haemorrhages were often observed (Gowers, 1904). Indeed, Moore (1925) suspected that "very few, if any, patients die of the disease without haemorrhages occurring a some period". Retinopathy was found in our most severe cases and this is in accord" with the findings of Cosnett and MacLeod (1959), Foulds (1963), and Adams, Chalmers Foulds, and Withey (1967). Rolleston (1923) and Cosnett and MacLeod (1959) though that the low platelet count so often found in severe pernicious anaemia was an importang factor in the pathogenesis of retinal haemorrhages, but in only one of our patients was the 
platelet count potentially low enough to cause haemorrhage. Both exudates and haemorrhages occur, and the haemorrhages may be superficial or deep. Their appearances have no diagnostic importance. When exudates are present the abnormalities may mimic albuminuric retinitis. Vision may be impaired (Adams and others, 1967), but both vision and retinal appearances are restored to normal after treatment.

Although retinal haemorrhages and exudates are comparatively less common in iron deficiency anaemia, the incidence is quite high in severe cases. In this series there were twelve patients in whom the $\mathrm{Hb}$ level was less than $7.0 \mathrm{~g}$. per $100 \mathrm{ml}$. and four of these had retinal haemorrhages or exudates. Surprisingly, both Gowers (1904) and Moore (1925) said that haemorrhages were -unusual in chlorosis although papilloedema seemed quite common. Nevertheless retinal haemorrhages and exudates were well known to occur in the anaemia of blood loss, and when Moore (1925) examined the fundi of 43 patients with blood loss anaemia, he found ten with retinal haemorrhages and two with exudates. Gowers (1904) also found a high incidence and remarked that retinopathy was more common after repeated haemorrhages, such as might occur in abortion, cupping, venesection, and leeching. These earlier observers looked for but never found retinal haemorrhages after blood loss due to war wounds or surgical operations. It is our impression that exudates tend to occur after chronic intermittent blood loss, whereas haemorrhages are more commonly found after an acute bleed. Two of our patients developed retinal haemorrhages alone; in one these occurred the day after a massive gastrointestinal haemorrhage from oesophageal varices, and the other patient was a young woman who had a factitious anaemia due to repeated self-venepuncture. Pears and Pickering (1960) described seven patients in whom retinal abnormalities were seen after loss of blood. Exudates were seen in five, and in two, haemorrhages were present. In one patient both haemorrhages and exudates were observed. In their cases there was a trend for retinal haemorrhages alone to occur very soon after the gastrointestinal bleeding, whereas observations made after an interval of more than 7 days usually revealed exudates.

Apart from two non-anaemic patients, one the control patient with carcinoma, and the other a patient with terminal Hodgkin's disease, exudates were observed only when anaemia was profound. Repeated examination of the fundi of patients with exudates showed that they cleared soon after the $\mathrm{Hb}$ concentration was raised by treatment or by blood transfusion. Recently much has been learned about the pathogenesis of soft exudates. Friedenwald (1949), in a histological study, noted that "cotton wool" spots were localized within the terminal bifurcation of precapillary arterioles and thought that they represented ischaemic infarcts. This has been confirmed experimentally by the injection of a suspension of minute glass spheres into the carotid artery of the pig, and noting the development within 24 hours of "cotton wool" exudates indistinguishable from those seen in man in hypertension (Dollery, Ramalho, Paterson, Hill, Henkind, Shakib, and Ashton, 1965; Dollery, Henkind, Paterson, Ramalho, and Hill, 1966). Friedenwald (1949) failed to find actual occlusion in the precapillary arterioles in the retinae of patients with hypertension who had retinal exudates, and concluded that the infarcts had come about because of vascular spasm. Dollery and others (1966) demonstrated in their experiments with intracarotid glass microspheres in the pig that a "cotton wool" exudate could occur even when the embolus moved on before 24 hours had elapsed. This suggested that retinal exudates may occur after temporary ischaemia. Retinal "cotton wool" exudates are now known to consist of swollen nerve fibres in the inner layers of the retina, and Shakib and Ashton (1966) have described them as representing a focal reaction of the 
injured axons of living nerve cells to ischaemia. Ashton and others (196I) describe histologically similar lesions to explain the retinal exudates that occur in severe bloog loss anaemia. It is therefore likely that severe anaemia can bring about spasm of the retinal arterioles and so cause infarction of the retina. Apart from indicating the severity of anaemia, retinal exudates have no diagnostic significance. The $\mathrm{Hb}$ threshold which they occur appears to lie between 6 and $7 \mathrm{~g}$. per $100 \mathrm{ml}$. Retinal exudates indi tinguishable from those found in hypertension and severe anaemia also occur after th occlusion of small retinal vessels by cholesterol emboli (Dark and Rizk, 1967) and fof emboli (DeVoe, 1950). Possibly the retinal exudates seen in disseminated carcinomos in the absence of anaemia are caused by precapillary occlusion by tumour cell embolit Similar lesions are also seen in the absence of anaemia during subacute bacterial end carditis and in vascular disease such as polyarteritis and systemic lupus erythematosus. $\frac{0}{0}$.

The group of control patients was examined to make sure that the high frequency of retinal abnormalities seen in patients with blood disease was not simply a reflection ô severe illness. Hawthorne (1922) mentioned the appearance of retinal haemorrhages in pneumonia, pyonephrosis, malignant disease of the viscera, and mitral disease. The cause of the retinal haemorrhages in our patient with acute pyelonephritis remains obscure. Retinal haemorrhages are known to occur in septicaemia, and it may well be that bacter aemia was present when the haemorrhage was noticed.

There seems to be no single cause of retinal haemorrhages in blood disease. On the whole their presence was related to the degree of anaemia and they may be a reflectiog of vascular damage caused by anaemic hypoxia. However, retinal haemorrhages are not associated with other diseases that cause hypoxia such as cyanotic congenital heal disease, though they occur occasionally in cases of respiratory failure due to chronic lunf disease. There is no doubt that leukaemic tissue may infiltrate the retina and give rise to haemorrhages in the absence of anaemia, and in one patient with chronic myeloid le $\mathbb{R}$ kaemia (Fig. 6) the presence of retinal haemorrhages seemed to be related to the total white cell count. Two patients with acute leukaemia developed retinal haemorrhages in the absence of marked anaemia. The $\mathrm{Hb}$ concentrations were 10.4 and $14.5 \mathrm{~g}$. per $100 \mathrm{~m}$ and the white cell counts raised to 658,000 and 43,000 per cu. mm. respectively. Fous patients with multiple myeloma developed retinal haemorrhages when the haemoglobih level was greater than $8.0 \mathrm{~g}$. per $100 \mathrm{ml}$. It is possible that the abnormal serum protein disturb the integrity of the endothelium of small blood vessels thereby increasing this threshold of haemoglobin concentration at which haemorrhages occur. Pears and Pickering (1960) discussed the possibility that retinal haemorrhages may be related to 8 rise in cerebrospinal fluid pressure and cited evidence to show that this occurs in seven anaemia. More recently Hayreh (1965) showed that in monkeys occlusion of the centrat retinal vein did not cause retinal haemorrhages unless arterial circulation was interferefét with at the same time. This supported the conclusion from a combined clinical and ophthalmological study by Paton, Rubinstein, and Smith (1964) that the highly charace teristic retinal appearances in central vein thrombosis are a reflection of the degree of arterial disease present. Severe anaemic hypoxia may well damage arteriolar endo응 thelium, and it is possible that the retinal haemorrhages are due to the combined effect off this and a high central retinal vein pressure. The presence of papilloedema in severe hypochromic anaemia can only be explained satisfactorily on the basis of raised intras cranial pressure. Papilloedema is not rare in leukaemia when complicated by meningead infiltration, but this did not occur in any of the patients in this series. Pears and Pickering (1960), in a detailed analysis of the clinical course of their patients, thought that in severe 
blood loss anaemia, episodes of hypotension may sometimes be an important aetiological factor in the development of retinal haemorrhages and exudates. They mentioned a patient without anaemia who developed small retinal haemorrhages soon after an episode of hypotension that complicated myocardial infarction. However, it seems a most unlikely explanation for the retinal haemorrhages seen in the wide spectrum of blood disease described here. Retinal haemorrhages were not seen when the sole abnormality in the peripheral blood was thrombocytopenia.

\section{Summary}

The fundus oculi of all patients with blood diseases seen in The Nuffield Department of Medicine, Oxford, during the course of one year was carefully examined in order to define the incidence of retinopathy in the various disorders of blood, to determine the diagnostic importance of lesions seen, and to relate the abnormalities found to the blood counts. I 52 patients were examined, and the retinae of 67 non-anaemic patients were examined as controls to make sure that the high incidence of retinopathy in blood disease was not simply a reflection of severe illness. When appropriate, examinations were repeated at intervals, and over 350 separate observations were made.

Retinal haemorrhages were common in acute leukaemia, chronic myeloid leukaemia, multiple myeloma, pernicious anaemia, and severe hypochromic or blood loss anaemia. The retinal abnormalities rarely had characteristics of diagnostic significance. On the whole, the presence of haemorrhages was related to the degree of anaemia present at the time. Occasionally, patients with leukaemia had retinal haemorrhages when the most striking abnormality in the peripheral blood was a high white blood cell count.

"Cotton wool" exudates similar to those that occur in hypertension were observed in fifteen patients with anaemia due to a variety of causes. The anaemia in all was profound and in only one was the $\mathrm{Hb}$ concentration greater than $6.6 \mathrm{~g}$. per $100 \mathrm{ml}$. Apart from reflecting the severity of anaemia, they had no diagnostic significance.

The retinal photographs were taken by Mr. E. W. Allen, Chief Optician, Oxford Eye Hospital, to whom we are especially grateful. We should like to thank Dr. Sheila Callender for her advice. Mr. John Anderson kindly helped with the statistical analysis of the results.

\section{References}

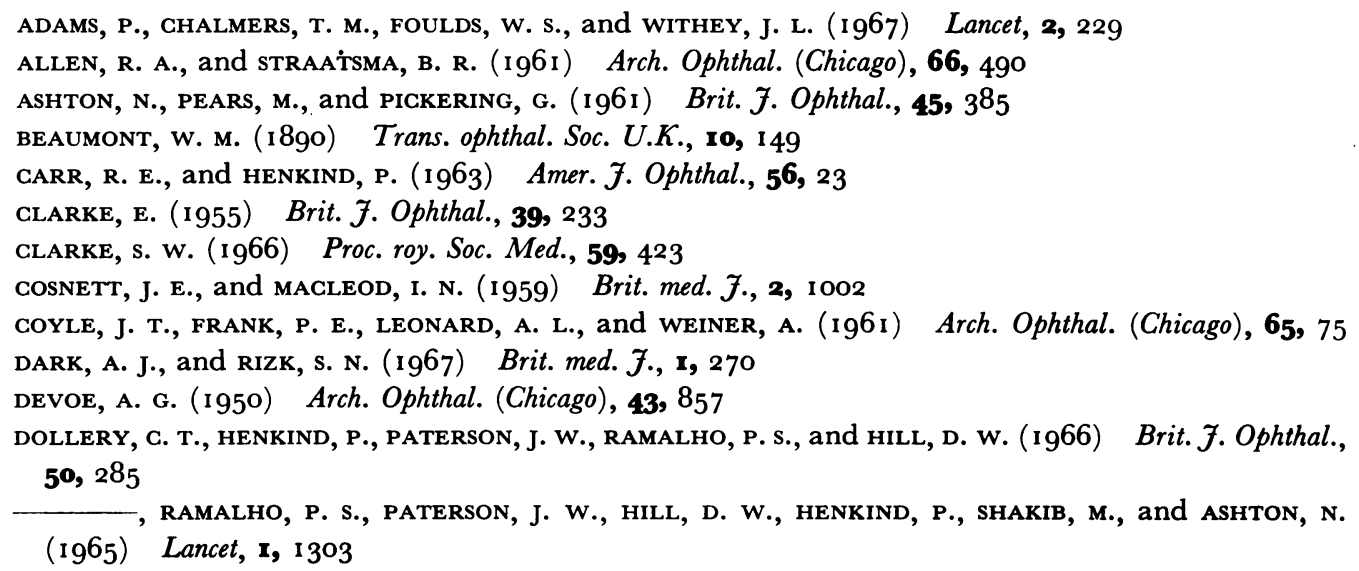




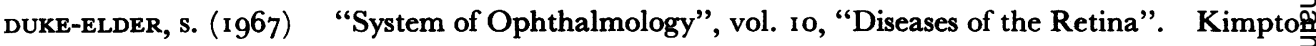

London

EALES, H. (1884) Ophthal. Rev., 3, 69

FERRIMAN, D. G., and ANDERSON, A. B. (1956) Brit. med. F., 2, 402

Foulds, w. s. (1963) Trans. ophthal. Soc. U.K., 83, 345

FRIEDENWALD, J. s. (1949) Amer. F. Ophthal., 32, 487

frost, w. ADAms (1896) "The Fundus Oculi". Young J. Pentland, Edinburgh and London

GAVEY, c. J. (1963) Trans. ophthal. Soc. U.K., 83, 315

GIBson, G. G. (1938) Arch. Ophthal. (Chicago), 20, 364

GOLDSTEIN, I., and WEXLER, D. (1935) Ibid., 13, 26

GOWERs, W. R. (1904) "A Manual and Atlas of Medical Ophthalmoscopy", 4th ed. Churchitt

London

HAWTHORNE, c. O. (1922) Brit. med. F., 2, 495

HAYREH, s. s. (1965) Brit. F. Ophthal., 49, 626

JONES, B., and Ashton, N. (1963) Trans. ophthal. Soc. U.K., 83, $4^{1} 3$

LARSEN, H. W. (1964) "Atlas of the Fundus of the Eye". Blackwell, Oxford

LIEBREICH, R. (1863) cited by Gowers (1904)

MACKENZIE, s. (1878) Lancet, 2, 797

( $188 \mathrm{I}) \quad$ Trans. ophthal. Soc. U.K., r, 48

MARShall, R. A. (1959) Blood, 14, 882

MARTin, N. H. (1960) Quart. F. Med., 29, 179

MASSA, J.-M., DE VLOO, N., and JAMOTTON, L. (1966)

Bull. Soc. belge Ophtal., No. I42, Fasc. I

MOORE, R. F. (1925) “Medical Ophthalmology", 2nd ed. Churchill, London NOver, A. (1966) "The Ocular Fundus". Lea and Febiger, Philadelphia PAtON, A., RUBinstein, K., and smith, v. H. (1964) Trans. ophthal. Soc. U.K., 84, 559 PEARs, M. A., and PICKering, G. (1960) Quart. F. Med., 29, 153

ROLleston, H. (1923) Trans. ophthal. Soc. U.K., 43, 110

SHAKIB, M., and AShTON, N. (Ig66) Brit. F. Ophthal., 50, 325

williams, R. (1884) Brit. med. F., 1, 10 